\title{
Production and Identification of Colchicine-derived Tetraploid Vaccinium darrowii and Its Use in Breeding
}

\author{
Dario J. Chavez and Paul M. Lyrene ${ }^{1}$ \\ Horticultural Sciences Department, University of Florida, 1301 Fifield Hall, Gainesville, FL 32611
}

\begin{abstract}
AdDiTIONAL INDEX wORDs. darrow's evergreen blueberry, unreduced gametes, breeding, polyploidy, Vaccinium corymbosum
Abstract. In Vaccinium L., most tetraploid hybrids between tetraploid cultivated highbush blueberry ( $V$. corymbosum $\mathrm{L}_{\text {.) }}$ and diploid darrow's evergreen blueberry ( $V$. darrowii Camp) have been produced by exploiting $V$. darrowii's tendency to produce $2 n$ gametes and a strong triploid block, which greatly reduces the number of triploid hybrids produced. Colchicine-derived tetraploids offer an alternative method of producing $V$. darrowii plants that will easily cross with tetraploid Vaccinium species. $V$. darrowii $(2 \mathrm{n}=2 \mathrm{x}=24)$ seeds were imbibed in $0.2 \%$ aqueous colchicine solution for $24 \mathrm{~h}$. The seeds were germinated and seedlings whose morphology suggested colchicine effects were selected at various stages of development. No macromorphological changes were consistently associated with chromosome doubling. However, stomatal guard cells and pollen size increased substantially as a result of chromosome doubling. Several types of plants were identified after colchicine treatment: 1) plants with a doubled LI (epidermal tissues) and LII (internal tissues) plant layers; 2) periclinal chimeras with a doubled LI layer and a normal LII; and 3) periclinal chimeras with a doubled LII layer and a normal LI. Of $\approx 4000$ seedlings that emerged from colchicine-treated seeds, 200 were selected for further examination based on leaf and stem morphology. Of the 200, five appeared to be tetraploid in LI, LII, or both layers based on stomatal guard cell size and pollen size. Crosses between colchicine-derived $V$. darrowii $(4 \mathrm{x})$ plants and southern highbush blueberry $(V$. corymbosum) cultivars $(4 \mathrm{x})$ were successful compared with $4 x-2 x$ and $2 x-4 x$ crosses using diploid $V$. darrowii and tetraploid southern highbush blueberry. Stomatal guard cells and pollen screening of the colchicine-treated plants were used as indicators of doubled $V$. darrowii plants and periclinal chimeras. The results from the crosses between colchicine-treated $V$. darrowii plants and tetraploid highbush blueberry cultivars confirmed the information obtained by stomata and pollen screening.
\end{abstract}

Various techniques have been used to overcome genetic crossing barriers between species in Vaccinium. Tetraploid blueberry plants have been produced by crossing diploid and tetraploid species. The production of unreduced gametes and the existence of a strong triploid block in Vaccinium have allowed the production of tetraploids from $4 \mathrm{x}-2 \mathrm{x}$ crosses and reciprocals (Cockerham and Galleta, 1976; Den Nijs and Peloquin, 1977; Johnston et al., 1980; Marks, 1966; Moore, 1965; Sharpe and Darrow, 1959; Sharpe and Shoemaker, 1958; Woodell and Valentine, 1961).

In the southern highbush blueberry breeding program at the University of Florida, many tetraploid hybrids have been produced using diploid $V$. darrowii's tendency to produce $2 \mathrm{n}$ gametes. It was originally thought that crossing $V$. darrowii (2x) with northern highbush blueberry cultivars $[V$. corymbosum $(4 \mathrm{x})$ ] would produce sterile triploid progeny (Sharpe and Darrow, 1959). Instead, Sharpe and Darrow obtained 31 tetraploid hybrids from 1600 flowers pollinated along with an unknown number of triploids. The $F_{1}$ hybrids were fertile and were easily intercrossed and backcrossed to tetraploid northern highbush blueberry cultivars.

Colchicine-derived tetraploids offer an alternative method of producing large populations of plants that will easily cross with tetraploid species of interest. Colchicine is thought to

Received for publication 26 Jan. 2009. Accepted for publication 20 Mar. 2009. We thank Dr. John W. Scott and Dr. David G. Clark for their suggestions and commentaries for the completion of this manuscript.

${ }^{1}$ Corresponding author. E-mail: lyrene@ufl.edu. induce tetraploidy by disrupting spindle formation during mitosis, resulting in cells with doubled chromosome number (Blakeslee, 1937). Colchicine has been widely tested and used for doubling chromosome numbers in various plant species (Dermen, 1940). Tetraploid $V$. darrowii plants could be useful in producing large populations of tetraploid hybrids when crossed with tetraploid Vaccinium species and cultivars.

Dermen and Bain (1944) treated runner tips or meristematic lateral buds of cranberry (Vaccinium macrocarpon Aiton) with colchicine. For identification of colchicine-derived plants, they reported that some runners, after treatment with colchicine, showed larger stems with shorter internodes and longer and broader leaves with larger stomata. Dermen and Bain (1944) described three types of colchicine-derived cranberry plants depending on the plant layers affected: 1) LI layer or epidermal tetraploids with all internal tissues unchanged; 2) LII layer or internal tetraploids with all internal tissues tetraploid but with the epidermis unchanged; and 3) LI and LII layers or total tetraploids with all tissues tetraploid. Because LII tissues normally produce the gametes, pollen diameter was a better screen for plants useful in breeding than stomatal guard cell size, which is an epidermal LI feature.

Dermen (1940) noted a correlation between nuclear volume and cellular volume in all cells. If cell volume increases after colchicine treatment, changes became apparent in certain plant parts such as leaf, flower, fruit, seeds, and so on. Chandler and Lyrene (1982) observed that diploid species in Vaccinium have shorter guard cells than hexaploid species. Thus, it should be possible to use guard cell length in Vaccinium to detect changes 
in LI ploidy levels after treatment with colchicine. Measurement of both stomatal guard cells and pollen tetrads could be used to detect polyploid changes in treated plants.

In blueberries, plants with doubled chromosome number have been produced using colchicine. A fertile decaploid plant (10x) was produced at Beltsville, MD, by treating a pentaploid plant obtained by crossing $V$. virgatum Aiton (6x) with northern highbush blueberry (4x) with colchicine (Moore, 1965). Lyrene and Perry (1982) treated in vitro shoot-tip cultures of rabbiteye blueberry $[V$. virgatum (6x)] cultivars and $V$. elliottii Chapm. (2x). Three $V$. virgatum and two $V$. elliottii fertile doubled plants were obtained. In another experiment, shoot-tip cultures of $V$. darrowii $(2 \mathrm{x}), V$. elliottii $(2 \mathrm{x})$, and $\mathrm{F}_{1}$ hybrids ( $V$. darrowii $\times V$. elliottii) were treated with colchicine dissolved in liquid modified Knops medium. No success was observed for $V$. darrowii treatments (Perry and Lyrene, 1984). In both experiments, shoot thickness in vitro was used as a screening method to find doubled colonies.

Within Vaccinium section Cyanococcus L., colchicinederived plants can be readily crossed with species of the same ploidy level. A colchicine-derived V. elliottii genotype, FL519, was crossed with tetraploid southern highbush blueberry cultivars. When diploid $V$. elliottii was crossed as a pollen parent with tetraploid cultivars, 0.01 seedlings per pollinated flower were obtained. When autotetraploid $V$. elliottii FL519 was used as a pollen parent, 3.86 seedlings per pollinated flower were obtained (Dweikat and Lyrene, 1991). The purpose of this study was to produce colchicine-derived $V$. darrowii $(4 \mathrm{x})$ plants that could be easily crossed with tetraploid southern highbush blueberry cultivars to produce a large progeny of tetraploid plants and to assess the value of the colchicine-derived $4 \mathrm{x} V$. darrowii in southern highbush blueberry breeding.

\section{Materials and Methods}

\section{Colchicine treatment}

Open-pollinated seeds from $V$. darrowii FL03-405, a plant propagated from Highlands County, FL, were collected. The pollen source consisted of $\approx 20$ other genotypes growing in pots surrounding FL03-405. Dried seeds were divided into two lots of $6.35 \mathrm{~g}$ each $(\approx 2000$ seeds per gram). One seed lot was assigned to each of the following colchicine treatments: 1) seed imbibed in $0.2 \%$ colchicine solution in distilled water for $96 \mathrm{~h}$; and 2 ) seed imbibed in $0.2 \%$ colchicine solution in distilled water for $96 \mathrm{~h}$ followed by one subsequent treatment, which is described subsequently. These treatments were selected based on previous experiments with colchicine seed treatment of diploid $V$. arboreum Marsh. (unpublished data).

For the first part of both treatments, colchicine was dissolved in distilled water by shaking for 4 to $5 \mathrm{~min}$. Each lot of $6.35 \mathrm{~g}$ of dried seeds was imbibed in $100 \mathrm{~mL}$ of aqueous colchicine solution for $96 \mathrm{~h}$ with aeration provided by shaking the flask approximately three times each day. The seeds were planted without rinsing in two 4-L nursery containers of 1:1 mix of sphagnum peat and perlite. After colchicine treatment, one seed lot was planted on the surface of sphagnum peat in one 4-L nursery container. The second seed lot was planted on a layer of peat in a plastic bowl that had holes in the bottom. This bowl was set on a 4-L nursery container filled with sphagnum peat, and peat was packed around the outside of the bowl. Two days after they were planted, the seeds in the bowl were treated a second time with colchicine. To make this treatment, the pot on which the bowl rested was immersed in water until the water level reached the seeds that were in the bowl. Aqueous colchicine solution $(0.1 \%)$ was then poured over the seeds, which were contained in a thin layer of wet peat in the bowl. By immersing the pot in water, it was possible to keep the added colchicine in the layer of peat that contained the seeds. The colchicine was kept around the seeds for $1 \mathrm{~h}$. The seeds were then removed from the bowl and planted without rinsing directly on the surface of the sphagnum peat in the 4-L nursery container. The containers were maintained in a greenhouse in Gainesville, FL, until germination was completed.

Two months after the seeds were sown, cotyledons from the planted seeds began to emerge. Thereafter, for the next 8 weeks, the seedlings were inspected everyday, and any seedlings that presented irregular morphology were transplanted to a tray filled with 1:1 sphagnum peat and perlite. Seedlings that showed unusual cotyledon size, coloration, shoot length, shoot morphology, shoot diameter, abnormal growth, or large size were selected as possible colchicine-derived plants. One hundred selected seedlings showing one or more of these characters were selected and transplanted for each treatment from a total of $\approx 2000$ seedlings that survived each treatment. Trays and nursery containers were maintained for 4 to 5 months in a greenhouse. As the seedlings grew, those that continued to show one or more of the characteristics described were maintained. Seedlings that became normal in appearance and morphology were eliminated.

From the 200 seedlings (100 from each treatment) that had been selected, 25 from Treatment 1 and 19 from Treatment 2 were maintained. These seedlings were transplanted to individual 4-L nursery containers filled with 1:1 sphagnum peat and perlite. The seedlings were maintained in the greenhouse until flowering.

\section{Stomatal guard cells and pollen screening}

When the selected genotypes started to flower, flowers and leaves were collected from each plant. The lower surfaces of three leaves per plant were covered with clear fingernail polish to obtain a print of the leaf lower epidermis. The dry prints were removed and placed on microscope slides for measurement. One or two drops of water were put on top of the three-leaf replicate and a $24 \times 50$-mm cover glass was slowly pressed over the top of the fingernail-polish prints on the microscope slide. Fifty to 80 stomata were examined per genotype. Pollen from three dry flowers was stained with $1 \%$ acetocarmine solution to measure pollen tetrad diameters. Thirty to 100 pollen tetrads were examined per genotype. Stomatal guard cell length and pollen tetrad diameter measurements were obtained using microphotographs taken with a Moticam 1000 1.3-megapixel microscope digital camera with the Motic Images Plus Version 2.0ML software (Motic Instruments, Richmond, BC, Canada) mounted on a light phase-contrast microscope (Leitz Microscope Co., Wetzlar, Germany), 250× and 400× magnification. The measurements were calibrated by photographing a microscope micrometer slide with the same camera setup and making direct comparisons.

Plants were classified into four groups after screening using the terminology of Dermen and Bain (1944) who used LI-LIILIII to designate the ploidy level of the LI, LII, and LIII histogenic layers. Because we did not determine the ploidy of the LIII histogenic layer, we did not report the "LIII" ploidy level. The classes observed after treatment were: 1) nondoubled 
plants with normal-sized stomatal guard cells and normal-sized pollen tetrads $(2 x-2 x) ; 2)$ periclinal chimeras with large stomatal guard cell length but pollen tetrads of normal size $(4 \mathrm{x}-2 \mathrm{x}) ; 3)$ periclinal chimeras with large pollen tetrads but stomatal guard cell length normal $(2 x-4 x)$; and 4) tetraploid plants with both pollen tetrads and stomatal guard cell length large $(4 x-4 x)$.

\section{Morphological studies of colchicine-derived plants}

Ten $2 \mathrm{x}-2 \mathrm{x} V$. darrowii genotypes, one $4 \mathrm{x}-2 \mathrm{x}$ periclinal chimera, three $2 x-4 x$ periclinal chimeras, and one $4 x-4 x$ plant were used in this study. These genotypes were used to search for flower, leaf, and berry morphological characters that distinguished each ploidy type. Five samples were measured for each character of each genotype. Leaf and flower characteristics were measured using a Traceable ${ }^{\circledR}$ Carbon Fiber Caliper (Fisher Scientific, Pittsburgh, PA).

Characteristics measured included leaf length, leaf width, corolla length, corolla width, diameter of corolla aperture, pedicel length, peduncle length, bracteole length, bracteole width, and diameter of the pedicel base. In addition, berries were weighed. To produce the berries, flowers of the plants with tetraploid LII layers were pollinated with pollen from colchicinederived tetraploid $V$. arboreum, and flowers of plants with diploid LII layers were pollinated with pollen from diploid $V$. darrowii. Twenty berries per plant were weighed for each category of plants after colchicine screening. Each plant was an experimental unit for all these measurements.

\section{Hybridization experiments}

Crosses With COlChicine-derived V. DARrowit $(4 \mathrm{x})$. Colchicine-derived $V$. darrowii plants were used in crosses with tetraploid southern highbush blueberry cultivars, colchicinederived $V$. arboreum $(4 \mathrm{x})$, and $V$. darrowii $(2 \mathrm{x})$ plants. Four colchicine-derived $V$. darrowii genotypes were selected, one $4 \mathrm{x}-4 \mathrm{x}$ and three $2 \mathrm{x}-4 \mathrm{x}$, because gametes are normally produced by LII tissues. These plants were referred to as "colchicinederived $V$. darrowii (4x)." Eight tetraploid highbush blueberry plants were crossed as female parents with the four colchicinederived $V$. darrowii (4x). The highbush blueberry cultivars were advanced selections from the Florida breeding program. In this article, for convenience, they are referred to as $V$. corymbosum, although other species (particularly $V$. darrowii) are present in their genetic background. In addition, the four colchicine-derived $V$. darrowii tetraploid plants were crossed as females with one colchicine-derived tetraploid plant of $V$. arboreum (FL06-730) and as males to diploid $V$. darrowii plants. Crosses between colchicine-derived $V$. darrowii and $V$. arboreum plants were made to obtain fertile high-vigor amphidiploid plants in comparison with sterile diploid plants obtained from crosses between diploid $V$. darrowii and $V$. arboreum (Brooks and Lyrene, 1995).

Pollen was dehisced onto the thumbnail and transferred by rubbing the stigma of the emasculated flower on the thumbnail. Twenty to 360 flowers were pollinated per plant for each cross, depending on flower availability. Berries were harvested when fully ripe. The first 20 ripe berries were individually opened. The seeds in each berry were counted and classified as plump or shriveled. The remaining berries were harvested, and seeds were extracted using a food blender (Moore, 1965). The seeds were washed with water, dried, and stored for 3 months in coin envelopes at $5^{\circ} \mathrm{C}$.
VACCINIUM DARROWII $(2 \mathrm{x}) \times V$. CORYMBOSUM $(4 \mathrm{x})$ CROSSES. Twelve tetraploid southern highbush blueberry cultivars were crossed as male and female parents with diploid $V$. darrowii. Three of the $V$. darrowii genotypes had been collected from the Florida peninsula near Lake Istokpoga and nine had been collected from the Florida panhandle in or near the Apalachicola Forest. Pollination, harvest, and seed extraction were as previously stated.

\section{Cytogenetic studies}

Flower buds at various developmental stages were collected from one periclinal $V$. darrowi chimera, designated as genotype 40, which produced large pollen tetrads after colchicine treatment. Flower buds were fixed in a 3:1 solution of glacial acetic acid absolute ethanol. Samples were kept in fixative until the pigments were removed and then stored in fixative at $5{ }^{\circ} \mathrm{C}$. The flower buds were then assessed for stage of development by cutting open a random floret from the several floret buds in one axillary bud, largest or smallest, and squashing two anthers on a microscope slide in $45 \%$ acetic acid. The slide was analyzed with a phase-contrast Leitz microscope $(250 \times$ and $400 \times)$ to determine whether the pollen mother cells were undergoing meiosis. When a meiotic bud was found, the additional eight anthers from that bud were digested for $3 \mathrm{~h}$ at room temperature in a $5 \%$ solution (diluted in citrate buffer at $\mathrm{pH} 6.0$ ) of cell wall degrading enzyme complex from Aspergillus sp. (Viscozyme ${ }^{\circledR}$; Novozymes, Bagsvaerd, Denmark). After digestion, the anthers were stored in $70 \%$ ethanol solution at $5{ }^{\circ} \mathrm{C}$. For chromosome counting, anthers were imbibed for $20 \mathrm{~min}$ at room temperature in $45 \%$ acetic acid. Four anthers were used to prepare each slide. Each anther was placed in one corner of a microscope slide area that could be covered by one coverslip. Each anther was divided into two or three portions to produce optimal squashing. Anthers were macerated in $45 \%$ acetic acid on the microscope slide. The coverslip was then placed on the slide. A medium-light tapping with the head of a pen was done over the coverslip at the points where the anthers were covered. Then the slide was heated lightly over a flame for $1 \mathrm{~s}$ and allowed to cool. Excess acetic acid was removed from the slide. The edges of the microscope cover glass were sealed with nail polish. Cells were observed in a phase-contrast Leitz microscope at $250 \times$ and $400 \times$ magnifications. Microphotographs were taken using Moticam 1000 1.3-megapixel microscope digital camera with the Motic Images Plus Version 2.0ML software. Chromosome pairing during meiosis was studied in three metaphase I cells. The number of univalents, bivalents, trivalents, and other chromosome associations at metaphase I were recorded.

\section{Statistical analysis}

Data were subjected to analysis of variance by the PROC GLM, and PROC FREQ procedures of SAS (Version 9.1; SAS Institute, Cary, NC). Means for stomatal guard cell length, pollen diameter, leaf, corolla, and fruit measurements were analyzed with Tukey's test and a significance level of 5\%. A $\chi^{2}$ "test of independence" at the 5\% significance level was used to test whether the two colchicine treatments differed in effectiveness $(\%)$.

Data analysis for each cross included fruit set percentage, number of plump seeds per pollinated flower (PPF), and number of seedlings per pollinated flower (SPF). Means for PPF and SPF for different treatments were separated using least squares means by Tukey's test with a significance level of 5\%. 
Means for fruit set percentage were separated using $\chi^{2}$ "test of independence" with a significance level of $5 \%$. In these $\chi^{2}$ tests, each pollinated flower was considered an observation with two possible responses: set or nonset. The null hypothesis of the $\chi^{2}$ "test of independence" was that the ratio of set to nonset was the same for the two crosses being compared.

\section{Results and Discussion}

Colchicine treatment. Abnormal growth and morphological changes were observed in some plants grown from seeds treated with colchicine. Morphological abnormalities for which the $V$. darrowii plants to be studied were preselected included changes in coloration from dark green to red on leaves and shoots, increase in shoot length, abnormal shoot morphology, and larger shoot diameter. An unusual growth habit, characterized by reduction or loss of apical dominance, was observed in two genotypes. Increases in leaf size (area) and shoot diameter were also present in some treated plants. Some colchicinederived $V$. darrowii plants were probably missed during the preselection stage. In cranberry, Dermen and Bain (1944) found that plants treated with colchicine often had abnormal shapes or showed sections of epidermis with enlarged stomatal guard cells. In our study, no distinctive general morphological differences were observed by which the colchicine-derived $V$. darrowii plants could be reliably distinguished. Thus, it was necessary to screen using stomatal guard cells and pollen size.

Stomatal GUARD CELlS AND POLLen SCREENING. Stomatal guard cells and pollen screening were efficient and distinctive indicators of colchicine-derived tetraploidy in $V$. darrowii. Both stomatal guard cell length and pollen tetrad diameter increased substantially in tetraploids (Fig. 1). Means for stomatal guard cell size of $4 x-4 x$ and $4 x-2 x$ plants were statistically higher than for $2 \mathrm{x}-4 \mathrm{x}$ and $2 \mathrm{x}-2 \mathrm{x}$ plants $(P<$
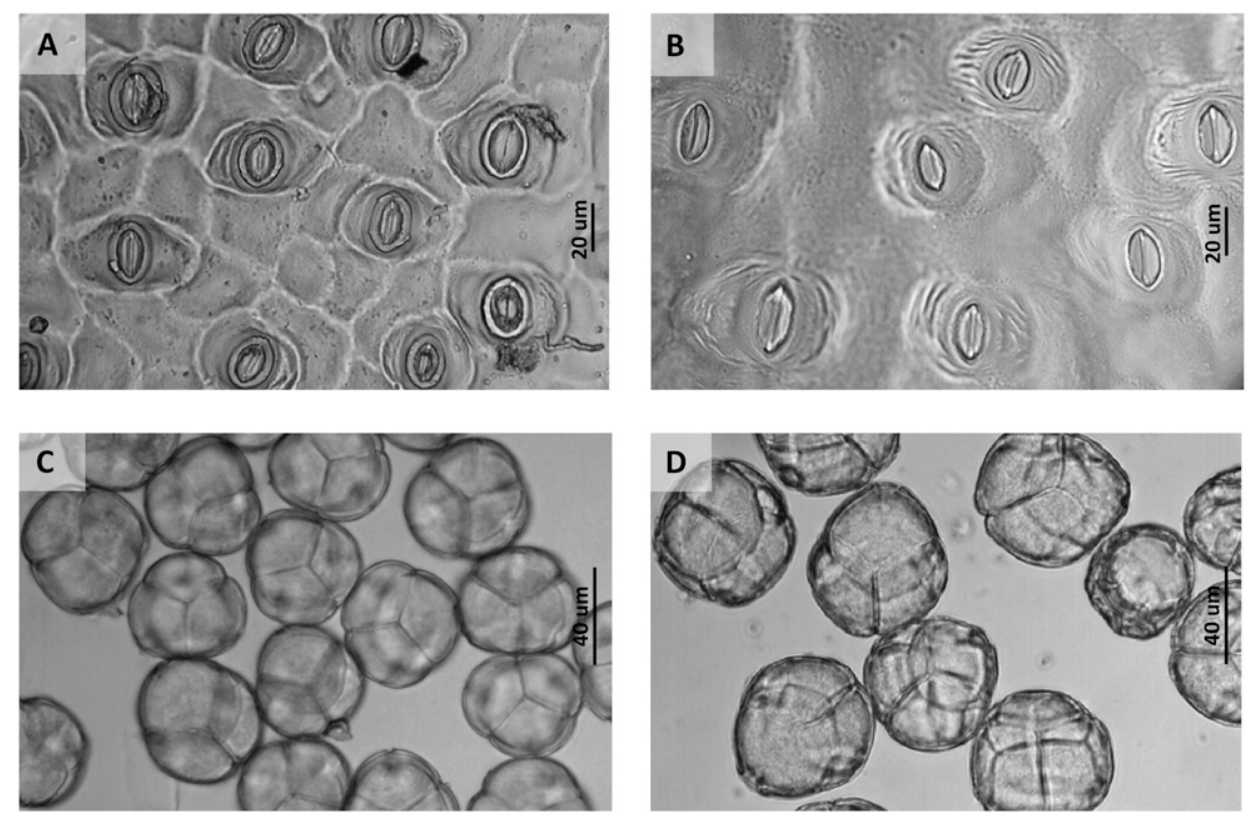

Fig. 1. Comparative differences between stomates (top) and pollen (bottom) microphotographs of normal and doubled Vaccinium darrowii plants selected for one or more morphological anomalies after colchicine treatment of seed. (A) Plants with normal LI (epidermal tissue) layer (2x-2x) and (B) doubled LI layer (4x-2x). (C) Plants with normal LII (internal tissue) layer $(2 x-2 x)$ and $(\mathbf{C})$ doubled LII layer $(2 x-4 x) ; 250 \times$.
$0.05)$. Means for pollen diameter of $4 x-4 x$ and $2 x-4 x$ were statistically higher than for $2 \mathrm{x}-2 \mathrm{x}$ and $4 \mathrm{x}-2 \mathrm{x}$ plants $(P<0.05)$ (Table 1).

Stomatal guard cell and pollen measurements for three untreated diploid $V$. darrowii plants and 44 selected colchicine-treated $V$. darrowii plants were used to calculate the population mean value $(\bar{x})$ for both measurements. Stomatal guard cell length and pollen diameter were larger in some colchicine-treated plants (Table 1). Unusually large stomatal guard cells were observed for six genotypes, averaging $22.7 \%$ to $39.0 \%$ longer than the population mean. The mean, which was based on 47 plants, included four that had large stomatal guard cells. Had these four plants been excluded in calculating the mean, the four would have deviated even further from the mean. Unusually large pollen was observed in five plants, the increases ranging from $15.5 \%$ to $30.2 \%$ over the population mean. These increases were visually distinctive by microscope at $250 \times$ magnification compared with plants with normal stomatal guard cells and pollen size (Fig. 1).

Two genotypes, VD-28 and VD-38, had large stomatal guard cells and normal pollen size and were classified as periclinal chimeras with doubled LI layer, $4 \mathrm{x}-2 \mathrm{x}$. Two genotypes, VD-17 and VD-26, had large stomatal guard cells and large pollen and were classified as plants with doubled LI and LII layers, $4 \mathrm{x}-4 \mathrm{x}$. Three genotypes, VD-36, VD-40, and VD43, had normal stomatal guard cells and large pollen and were classified as periclinal chimeras with a doubled LII layer, $2 \mathrm{x}-4 \mathrm{x}$.

Stomatal guard cell length and pollen diameter measurements were an efficient way to screen for polyploid changes after colchicine treatment. Both measurements were necessary to identify the various types of periclinal chimeras that can be produced. Screening by pollen diameter alone should be sufficient to identify genotypes that would breed like tetraploids, but this requires that screening be delayed until the plants are old enough to flower. Both the work reported here and the study by Chandler and Lyrene (1982) indicated that periclinal chimeras after colchicine treatment of blueberries are so frequent that screening for plants that breed like tetraploids by examining stomatal guard cell size is of limited value.

The difference between the two colchicine treatments in the rate of production of tetraploid plants was not statistically significant, but this is not surprising given the small number of tetraploid plants produced (Table 2). Treatment 2, which included a second colchicine application, produced six polyploid or periclinal chimera plants, and Treatment 1 , which had only the initial seed soak, produced one. From the seven colchicine-derived plants, four crossed readily with tetraploid plants. No differences were detected in the types of colchicine-derived plants produced by the two treatments. 
Table 1. Measurements of stomatal guard cell length and pollen diameter for Vaccinium darrowii plants selected for one or more morphological anomalies after colchicine-treatment of seed. ${ }^{z}$

\begin{tabular}{|c|c|c|c|c|c|c|}
\hline \multirow{2}{*}{ Plant $^{y}$} & \multicolumn{3}{|c|}{$\begin{array}{l}\text { Stomatal guard } \\
\text { cell length }(\mu \mathrm{m})\end{array}$} & \multicolumn{3}{|c|}{$\begin{array}{l}\text { Pollen diam } \\
\qquad(\mu \mathrm{m})\end{array}$} \\
\hline & Мean & $\mathrm{SE}$ & $\begin{array}{l}(\mathrm{x}-\bar{x}) / \mathrm{x} \\
(0 \%)^{\mathrm{x}}\end{array}$ & Mean & $\mathrm{SE}$ & $(\mathrm{x}-\bar{x}) / \mathrm{x}$ \\
\hline 03402-I & 15.3 & 0.21 & -6.6 & 52.9 & 0.29 & 13.6 \\
\hline 03404-I & 15.1 & 0.20 & -7.7 & 40.1 & 0.29 & -12.4 \\
\hline 03405-I & 17.1 & 0.19 & 4.7 & 44.6 & 0.29 & -3.3 \\
\hline Genotype 1 & 15.2 & 0.18 & -7.1 & 45.0 & 0.31 & -2.4 \\
\hline Genotype 10 & 15.5 & 0.20 & -5.3 & 50.1 & 0.54 & 7.9 \\
\hline Genotype 11 & 17.2 & 0.19 & 5.1 & 43.8 & 0.41 & -4.9 \\
\hline Genotype 12 & 15.1 & 0.18 & -7.6 & 44.0 & 0.29 & -4.4 \\
\hline Genotype 13 & 16.3 & 0.19 & -0.1 & 44.6 & 0.39 & -3.2 \\
\hline Genotype 14 & 13.5 & 0.20 & -17.2 & 42.5 & 0.34 & -7.5 \\
\hline Genotype 15 & 16.4 & 0.27 & 0.3 & 44.9 & 0.29 & -2.6 \\
\hline Genotype 16 & 16.9 & 0.20 & 3.6 & 45.5 & 0.27 & -1.5 \\
\hline Genotype 17 & 22.7 & 0.21 & 39.0 & 54.6 & 0.41 & 17.2 \\
\hline Genotype 18 & 15.3 & 0.21 & -6.2 & 46.4 & 0.34 & 0.4 \\
\hline Genotype 19 & 16.1 & 0.21 & -1.3 & 45.2 & 0.28 & -2.1 \\
\hline Genotype 2 & 15.5 & 0.25 & -4.9 & 45.1 & 0.33 & -2.2 \\
\hline Genotype 20 & 15.5 & 0.20 & -4.8 & 50.4 & 0.32 & 8.6 \\
\hline Genotype 21 & 15.5 & 0.20 & -5.2 & 45.0 & 0.38 & -2.4 \\
\hline Genotype 22 & 15.8 & 0.22 & -3.4 & 43.4 & 0.27 & -5.6 \\
\hline Genotype 23 & 16.9 & 0.18 & 3.6 & 44.1 & 0.35 & -4.3 \\
\hline Genotype 24 & 16.4 & 0.19 & 0.3 & 42.9 & 0.36 & -6.7 \\
\hline Genotype 25 & 16.0 & 0.18 & -1.9 & 44.2 & 0.29 & -4.0 \\
\hline Genotype 26 & 20.0 & 0.23 & 22.7 & 53.8 & 0.37 & 15.5 \\
\hline Genotype 27 & 17.1 & 0.18 & 4.9 & 44.4 & 0.31 & -3.6 \\
\hline Genotype 28 & 20.9 & 0.22 & 28.0 & 42.7 & 0.31 & -7.1 \\
\hline Genotype 29 & 16.7 & 0.18 & 2.0 & 43.7 & 0.32 & -5.0 \\
\hline Genotype 3 & 15.6 & 0.20 & -4.4 & 40.1 & 0.32 & -12.5 \\
\hline Genotype 30 & 15.2 & 0.22 & -6.7 & 47.3 & 0.27 & 2.3 \\
\hline Genotype 31 & 15.7 & 0.18 & -3.6 & 48.5 & 0.33 & 4.8 \\
\hline Genotype 32 & 16.0 & 0.22 & -1.9 & 45.7 & 0.26 & -1.0 \\
\hline Genotype 33 & 16.3 & 0.17 & -0.3 & 43.0 & 0.26 & -6.5 \\
\hline Genotype 34 & 15.3 & 0.19 & -6.5 & 44.8 & 0.34 & -2.7 \\
\hline Genotype 35 & 17.6 & 0.20 & 7.8 & 43.9 & 0.26 & -4.6 \\
\hline Genotype 36 & 15.1 & 0.19 & -7.3 & 61.0 & 0.48 & 30.2 \\
\hline Genotype 37 & 17.2 & 0.19 & 5.6 & 44.1 & 0.28 & -4.2 \\
\hline Genotype 38 & 21.7 & 0.20 & 33.1 & 46.0 & 0.34 & -0.5 \\
\hline Genotype 39 & 15.3 & 0.20 & -6.1 & 45.9 & 0.59 & -0.5 \\
\hline Genotype 4 & 16.8 & 0.20 & 2.7 & 43.9 & 0.32 & -4.7 \\
\hline Genotype 40 & 15.8 & 0.20 & -3.1 & 59.7 & 0.37 & 27.5 \\
\hline Genotype 41 & 14.4 & 0.19 & -11.9 & $\underline{ }^{\mathrm{w}}$ & - & - \\
\hline Genotype 42 & 17.0 & 0.21 & 4.2 & 46.6 & 0.30 & 0.8 \\
\hline Genotype 43 & 15.4 & 0.19 & -5.7 & 59.1 & 0.44 & 26.3 \\
\hline Genotype 44 & 14.9 & 0.17 & -8.9 & 42.3 & 0.27 & -7.9 \\
\hline Genotype 5 & 14.9 & 0.18 & -8.5 & 44.6 & 0.34 & -3.2 \\
\hline Genotype 6 & 16.5 & 0.16 & 1.3 & 43.0 & 0.34 & -6.5 \\
\hline Genotype 7 & 15.9 & 0.19 & -2.6 & 44.3 & 0.38 & -3.9 \\
\hline Genotype 8 & 15.8 & 0.17 & -3.1 & 41.6 & 0.34 & -9.4 \\
\hline Genotype 9 & 15.0 & 0.21 & -7.9 & 45.4 & 0.28 & -1.5 \\
\hline
\end{tabular}

continued on next column

Analysis of morphological characteristics of COLCHICINE-DERIVED PLANTS. Vaccinium darrowii 4x-4x plants, $4 \mathrm{x}-2 \mathrm{x}$ and $2 \mathrm{x}-4 \mathrm{x}$ periclinal chimeras, and diploid $V$. darrowii plants were not morphologically different between groups
Table 1. Continued.

\begin{tabular}{|c|c|c|c|c|c|c|}
\hline \multirow[b]{3}{*}{ Plant $^{\mathrm{y}}$} & \multicolumn{3}{|c|}{$\begin{array}{l}\text { Stomatal guard } \\
\text { cell length }(\mu \mathrm{m})\end{array}$} & \multicolumn{3}{|c|}{$\begin{array}{l}\text { Pollen diam } \\
(\mu \mathrm{m})\end{array}$} \\
\hline & & & $(\mathrm{x}-\bar{x}) / \mathrm{x}$ & & & $(\mathrm{x}-\bar{x}) / \mathrm{x}$ \\
\hline & Mean & $\mathrm{SE}$ & $(\%)^{x}$ & Mean & $\mathrm{SE}$ & $(\%)^{x}$ \\
\hline $\begin{array}{l}\text { Population } \\
\text { mean }(\bar{x})\end{array}$ & 16.3 & 0.20 & 0.0 & 46.2 & 0.34 & 0.0 \\
\hline VD mean & $15.9 \mathrm{~b}^{\mathrm{u}}$ & 0.14 & - & $44.8 \mathrm{c}$ & 0.39 & - \\
\hline VDI mean & $21.3 \mathrm{a}$ & 0.63 & - & $44.3 \mathrm{c}$ & 1.72 & - \\
\hline VDII mean & $15.4 \mathrm{~b}$ & 0.52 & - & $59.9 \mathrm{a}$ & 1.40 & - \\
\hline $\begin{array}{l}\text { VDI and II } \\
\text { mean }\end{array}$ & $21.4 \mathrm{a}$ & 0.63 & - & $54.2 \mathrm{~b}$ & 1.72 & - \\
\hline
\end{tabular}

${ }^{\mathrm{z}}$ Each mean is based on measurements of 50 to 80 stomatal guard cells and 30 to 100 pollen tetrads.

${ }^{y}$ Bold and italic letters indicate plants with an increase of more than $20 \%$ in stomatal guard cell length or more than $15 \%$ in pollen diameter compared with the population mean $(\bar{x})$.

${ }^{x}$ Percentage of increase or decrease from the population mean $(\bar{x})$.

${ }^{\mathrm{w}}$ Missing data.

${ }^{\mathrm{v}} \mathrm{VD}=$ diploid $V$. darrowii $(2 \mathrm{x}-2 \mathrm{x}), 39$ plants; $\mathrm{VDI}=V$. darrowii periclinal chimera with large stomatal guard cells but pollen tetrads normal size $(4 \mathrm{x}-2 \mathrm{x})$, two plants; $\mathrm{VDII}=V$. darrowii periclinal chimera with large pollen tetrads but stomatal guard cell length normal size $(2 \mathrm{x}-4 \mathrm{x})$, three plants; VDI and II $=V$. darrowii with both pollen tetrads and stomatal guard cell length large $(4 x-4 x)$, two plants.

"Similar letters within a column indicates means not significantly different, Tukey's test, $\alpha=0.05$.

(Table 3). The characteristics that were studied could not be used to visually distinguish among $4 x-4 x, 2 x-4 x, 4 x-2 x$, and diploid $V$. darrowii plants in future treatments. Berry weight measurements were not different among groups. Results were similar to those of cranberry in which Dermen and Bain (1944) observed highly variable morphological changes after colchicine treatment.

The results of the morphology studies of the colchicinederived $V$. darrowii plants were not significantly different at $P=$ 0.05 as a result of low replication number within categories (Table 3). Stomatal guard cells and pollen screening were by far the best methods for identifying colchicine-derived tetraploid $V$. darrowii plants.

Hybridization EXPERIMENTs. Crosses between colchicinederived $V$. darrowii $(4 \mathrm{x})$ plants and tetraploid southern highbush blueberry cultivars $(V$. corymbosum) were readily made. Fruit set of $V$. corymbosum $(4 \mathrm{x}) \times V$. darrowii $(4 \mathrm{x})$ ranged from $30.8 \%$ to $75.6 \%$ (Table 4$)$. In V. corymbosum $(4 \mathrm{x}) \times V$. darrowii (2x) crosses, fruit set ranged from $0.3 \%$ to $46.0 \%$ (Table 5 , data from individual crosses not shown). Fruit set of $V$. darrowii $(2 \mathrm{x}) \times$ $V$. corymbosum (4x) ranged from $2.76 \%$ to $64.04 \%$ (Table 5 , data from individual crosses not shown). When used to pollinate tetraploid highbush blueberry, pollen from tetraploid $V$. darrowii resulted in higher fruit set, berry weight, number of seeds per berry, PPF, and SPF than pollen from diploid $V$. darrowii $(P<0.05$; Table 5$)$. It has been reported previously in Vaccinium that crosses between species of the same ploidy level are much more productive than diploid $\times$ tetraploid crosses (Darrow et al., 1949; Meader and Darrow, 1944; Rousi, 1966; Sharpe, 1953; Sharpe and Darrow, 1959).

It remains to be seen whether large populations of tetraploid $V$. darrowii can be obtained from crosses between diploid and tetraploid $V$. darrowii. Results of the two $V$. darrowii $(2 \mathrm{x}) \times V$. darrowii (4x) crosses are shown individually in Table 4 . These 
crosses were made using as female a diploid $V$. darrowii plant that produces numerous 2n eggs, FL06-660-I (Chavez, 2008). A different pollen composite was used in each cross. Each composite was a mix of pollens from two distinct $V$. darrowi genotypes that produced large pollen. Fruit set was $33.8 \%$ and $54.3 \%$ for the two crosses, PPF was 1.78 to 3.28 , and SPF was

Table 2. Colchicine doubling rate after aqueous treatments of Vaccinium darrowii seed. ${ }^{\mathrm{z}}$

\begin{tabular}{lcccccc}
\hline Treatment ${ }^{\mathrm{y}}$ & $\begin{array}{c}\text { Seeds } \\
(\mathrm{g})\end{array}$ & $\begin{array}{c}\text { Plants } \\
(\text { no. })\end{array}$ & $\begin{array}{c}\text { First } \\
\text { selection (no.) }\end{array}$ & $\begin{array}{c}\text { Second } \\
\text { selection (no. })^{\mathrm{x}}\end{array}$ & $\begin{array}{c}\text { Doubled } \\
\text { plants (no.) }\end{array}$ & $\begin{array}{c}\text { Rate } \\
\text { doubled (\%) }\end{array}$ \\
\hline $\mathrm{T} 1$ & 6.35 & $\approx 2,000$ & 100 & 25 & 1 & 0.05 NS \\
$\mathrm{T} 2$ & 6.35 & $\approx 2,000$ & 100 & 19 & 6 & 0.30 \\
\hline
\end{tabular}

${ }^{\mathrm{z}}$ Number of plants germinated and selected that presented one or more morphological anomalies after colchicine treatment of seed.

${ }^{\mathrm{y}} \mathrm{T} 1=$ seed imbibed in $0.2 \%$ aqueous colchicine solution for $96 \mathrm{~h}$; $\mathrm{T} 2=$ seed imbibed in $0.2 \%$ aqueous colchicine solution for $96 \mathrm{~h}+$ retreatment after planting with $0.1 \%$ aqueous colchicine solution for $1 \mathrm{~h}$.

${ }^{x}$ Selection of plants with abnormal morphology.

${ }^{\text {w}}$ Includes plants with both LI (epidermal tissues) and LII (internal tissues) doubled and periclinal chimeras with either LI or LII doubled.

NS $=$ indicates means not significantly different within a column, $\chi^{2}$, "test of independence," $\alpha=0.05$.
0.12 and 0.64 (Table 4 ). These results were similar to those from $V$. darrowii $(2 \mathrm{x}) \times V$. corymbosum $(4 \mathrm{x})$ crosses with mean set of $33.8 \%$, PPF of 1.40 , and SPF of 0.04 (Table 5). In erosses, $2 n$ egg production by $V$. darrowi presumably allowed these hybridizations to occur. Colchicinederived tetraploid $V$. darrowii and tetraploid $V$. corymbosum, when used to pollinate diploid $V$. darrowii, did not differ significantly in mean fruit set, total number of seeds per berry, PPF, and SPF (Table 5). A large number of seedlings were obtained from $V$. corymbosum $(4 \mathrm{x}) \times$ colchicine-derived $V$. darrowii (4x) with an SPF of 2.30 (Table 5).

Vaccinium darrowii $(2 \mathrm{x}) \times V$. darrowii $(4 \mathrm{x})$ crosses were compared with $V$. darrowii $(2 \mathrm{x}) \times V$. darrowii $(2 \mathrm{x})$ crosses (data not shown). Fruit set from the homoploid crosses ranged from $51.2 \%$ to $100 \%$. Fruit set and PPF were 1.6x

Table 3. Leaf and corolla characteristics of 10 diploid Vaccinium darrowii plants, four $V$. darrowii periclinal chimeras, and one tetraploid V. darrowii plant grown from colchicine-treated seed. ${ }^{\mathrm{z}}$

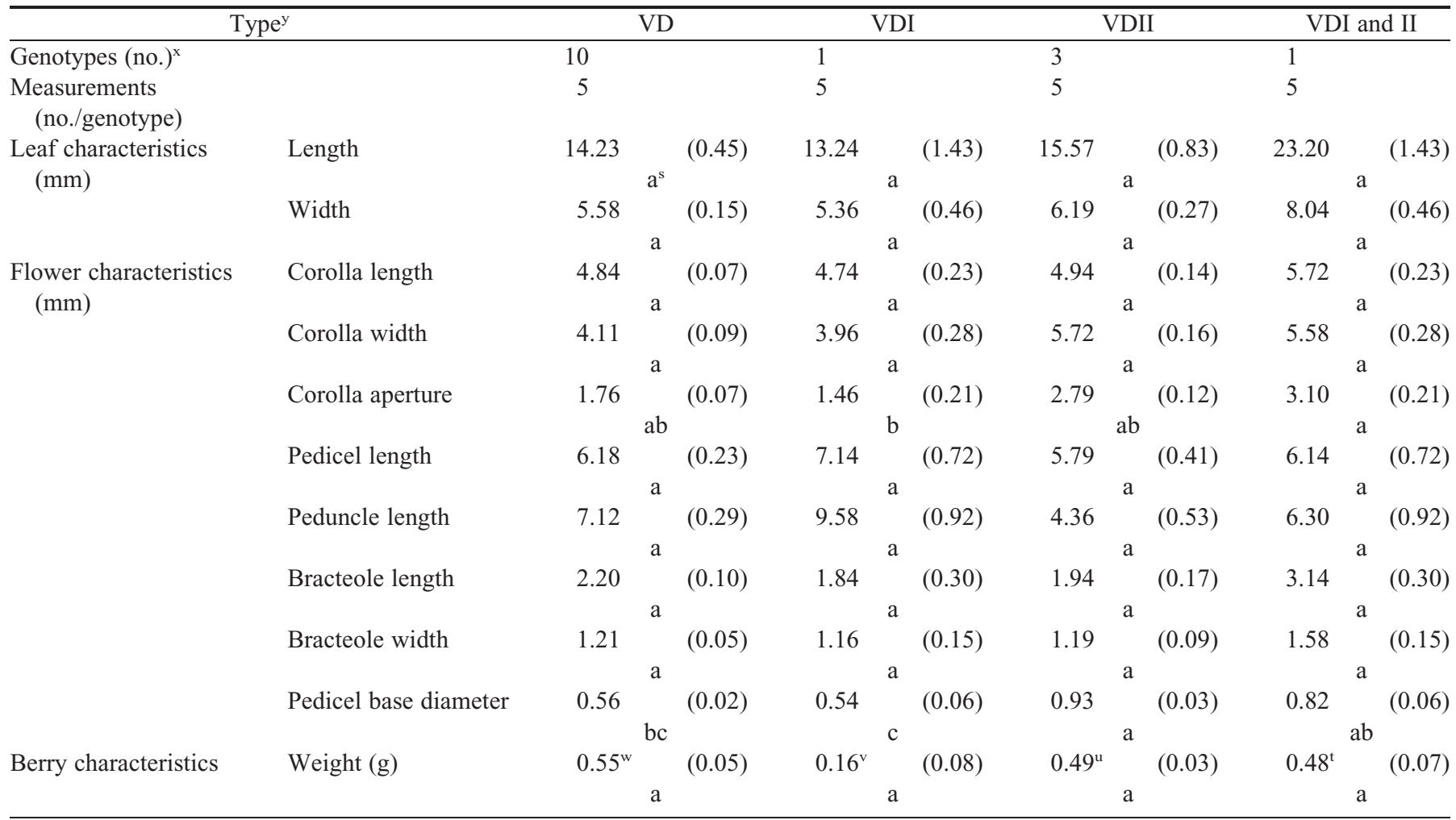

"Plants were $\approx 2$ years old when measured. Values within the table are mean (SE).

${ }^{\mathrm{y}} \mathrm{VD}=$ diploid $V$. darrowii $(2 \mathrm{x}-2 \mathrm{x}) ; \mathrm{VDI}=V$. darrowii periclinal chimera with large stomatal guard cells but pollen tetrads normal size $(4 \mathrm{x}-2 \mathrm{x})$; $\mathrm{VDII}=V$. darrowii periclinal chimera with large pollen tetrads but stomatal guard cell length normal size $(2 \mathrm{x}-4 \mathrm{x})$; VDI and II $=V$. darrowii with both pollen tetrads and stomatal guard cell length large $(4 x-4 x)$.

${ }^{\mathrm{x}}$ Each plant was an experimental unit.

${ }^{\mathrm{w}}$ One plant, 20 berries.

${ }^{\mathrm{v}}$ One plant, seven berries.

"Three plants, 54 berries.

${ }^{t}$ One plant, 10 berries. VDII and VDI and II berries resulted from crosspollinations with pollen from colchicine-derived $V$. arboreum (4x-4x).

VDI and VD berries resulted from crosspollinations with pollen from diploid $V$. darrowii.

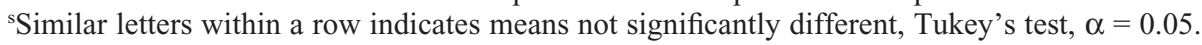


Table 4. Result of interspecific hybridization between tetraploid southern highbush blueberry cultivars (Vaccinium corymbosum), diploid Vaccinium darrowii, colchicine-derived Vaccinium arboreum (4x), and colchicine-derived $V$. darrowii genotypes in 2008 .

\begin{tabular}{|c|c|c|c|c|c|c|c|}
\hline Crosses & & & $\begin{array}{c}\text { Flowers } \\
\text { pollinated } \\
\text { (no.) }\end{array}$ & $\begin{array}{c}\text { Berries } \\
\text { (no.) }\end{array}$ & $\begin{array}{c}\text { Fruit } \\
\text { set }(\%)\end{array}$ & $\begin{array}{l}\mathrm{PPF}^{\mathrm{x}} \\
\text { (no.) }\end{array}$ & $\begin{array}{l}\mathrm{SPF}^{\mathrm{w}} \\
\text { (no.) } \\
\end{array}$ \\
\hline Highbush $^{z}$ & $x$ & $\begin{array}{l}\text { Colchiploid } \\
\text { V. darrowi } i^{\mathrm{y}}\end{array}$ & & & & & \\
\hline 02-106-HB & $\times$ & $40-2 x-4 x$ & 359 & 206 & 57.4 & 4.39 & 2.19 \\
\hline 04-103-HB & $x$ & $40-2 x-4 x$ & 119 & 90 & 75.6 & 7.80 & 5.25 \\
\hline 03-161-HB & $x$ & $17-4 x-4 x$ & 26 & 18 & 69.2 & 0.23 & 0.12 \\
\hline 00-211-HB & $x$ & $17-4 x-4 x$ & 383 & 118 & 30.8 & 1.52 & 0.82 \\
\hline 05-323-HB & $x$ & $36-2 x-4 x$ & 53 & 30 & 56.6 & 4.59 & 2.42 \\
\hline 00-211-HB & $x$ & $36-2 x-4 x$ & 249 & 173 & 69.5 & 9.32 & 4.20 \\
\hline 03-291-HB & $\times$ & $43-2 x-4 x$ & 74 & 51 & 68.9 & 2.87 & 0.74 \\
\hline 00-211-HB & $x$ & $43-2 x-4 x$ & 312 & 185 & 59.3 & 6.13 & 2.68 \\
\hline $\begin{array}{l}\text { Colchiploid } \\
\text { V. darrowii }\end{array}$ & $x$ & $\begin{array}{l}\text { Colchiploid } \\
\text { V. arboreum }\end{array}$ & & & & & \\
\hline $17-4 x-4 x$ & $x$ & 06-730-VA $2 x-4 x$ & 176 & 31 & 17.6 & 0.56 & 0.19 \\
\hline $40-2 x-4 x$ & $x$ & 06-730-VA $2 x-4 x$ & 87 & 53 & 60.9 & 5.72 & 0.93 \\
\hline $36-2 x-4 x$ & $x$ & 06-730-VA $2 x-4 x$ & 234 & 37 & 15.8 & 0.39 & 0.08 \\
\hline $43-2 x-4 x$ & $x$ & 06-730-VA $2 x-4 x$ & 24 & 14 & 58.3 & 4.50 & 0.96 \\
\hline V. darrowii ${ }^{\mathrm{u}}$ & $x$ & $\begin{array}{l}\text { Colchiploid } \\
\text { V. darrowii }\end{array}$ & & & & & \\
\hline FL06-660-I & $x$ & $40+43$ VDcomp & 275 & 93 & 33.8 & 1.79 & 0.12 \\
\hline FL06-660-I & $\times$ & 17 + 36 VDcomp & 265 & 144 & 54.3 & 3.28 & 0.64 \\
\hline
\end{tabular}

${ }^{\mathrm{z}}$ Tetraploid $V$. corymbosum, southern highbush blueberry.

${ }^{\mathrm{y}}$ The first number of these names indicates a particular $V$. darrowii genotypes. The next two numbers indicate the ploidy of LI (epidermal tissues) and LII (internal tissues) layers as inferred from stomatal guard cell length and pollen tetrad diameter, respectively.

${ }^{x} \mathrm{PPF}=$ plump seeds per pollinated flower.

${ }^{\mathrm{w}} \mathrm{SPF}=$ seedlings per pollinated flower.

vThe first number of this name indicates a particular genotype. VA indicates the species, V. arboreum. The next two numbers indicate the ploidy of LI and LII layers as inferred from stomatal guard cell length and pollen tetrad diameter, respectively.

"Diploid $V$. darrowii (florida evergreen blueberry); $\mathrm{I}=$ Istokpoga race.

${ }^{t}$ Colchicine-derived $V$. darrowii. Genotype 36, 40, 43 = periclinal chimeras with doubled LII layer and nondoubled LI layer; genotype 17 = plant with doubled LI and LII layers; VDcomp $=V$. darrowii composite.

Table 5. Result of crossing colchicine-derived Vaccinium darrowii plants with other Vaccinium species measured by fruit set (\%), berry weight (g), number of seeds per berry, number of plump seeds per pollinated flower, and number of seedlings per pollinated flower.

\begin{tabular}{|c|c|c|c|c|c|c|c|c|c|c|}
\hline \multicolumn{3}{|c|}{ Cross type $^{z}$} & $\begin{array}{c}\text { Crosses } \\
\text { (no.) }\end{array}$ & $\begin{array}{c}\text { Flowers } \\
\text { (no.) }\end{array}$ & $\begin{array}{c}\text { Berries } \\
\text { (no.) }\end{array}$ & $\begin{array}{c}\text { Fruit set } \\
(\%)\end{array}$ & $\begin{array}{l}\text { Wt } \\
(\mathrm{g})^{\mathrm{y}}\end{array}$ & $\begin{array}{l}\text { Seeds } \\
(\bar{x})^{\mathrm{x}}\end{array}$ & $\begin{array}{l}\mathrm{PPF}^{\mathrm{w}} \\
\text { (no.) }\end{array}$ & $\begin{array}{l}\mathrm{SPF}^{\mathrm{v}} \\
\text { (no.) }\end{array}$ \\
\hline HB & $x$ & VD- & 8 & 1,575 & 871 & $60.9 \mathrm{a}^{\mathrm{u}}$ & $2.2 \mathrm{a}$ & $46.6 \mathrm{a}$ & $4.61 \mathrm{a}$ & $2.30 \mathrm{a}$ \\
\hline $\mathrm{HB}$ & $\times$ & VD- & 12 & 4,875 & 258 & $76 \mathrm{c}$ & $1.4 \mathrm{~b}$ & 8. & $0.08 \mathrm{~b}$ & $0.03 \mathrm{~b}$ \\
\hline VD-2x & $x$ & VD-4x & 2 & 540 & 237 & 44. & $0.6 \mathrm{c}$ & $33.7 \mathrm{~b}$ & $2.54 \mathrm{ab}$ & $0.38 \mathrm{~b}$ \\
\hline VD-2x & $x$ & HB & 15 & 5,122 & 2,304 & $33.8 \mathrm{~b}$ & $0.3 \mathrm{~d}$ & $39.4 \mathrm{ab}$ & $1.40 \mathrm{~b}$ & $0.04 \mathrm{~b}$ \\
\hline
\end{tabular}

$\overline{{ }^{\mathrm{z}} \mathrm{HB}}=$ tetraploid southern highbush blueberry $($ V. corymbosum $)$, VD-4x $=$ colchicine-derived tetraploid $V$. darrowii (genotype 17, 36, 40 and 43); VD-2x = diploid $V$. darrowii.

${ }^{y}$ Berry weight, 20 berries per cross.

${ }^{\mathrm{x}}$ Seeds per berry.

${ }^{\text {wPPF }}=$ plump seeds per pollinated flower.

${ }^{\mathrm{v}} \mathrm{SPF}=$ seedlings per pollinated flower.

"Similar letters within a column indicates means not significantly different. Tukey's test for weight, total seeds and PPF, $\alpha=0.05 . \chi^{2}$, "test of independence" for fruit set, $\alpha=0.05$.

and $6 \mathrm{x}$, respectively, higher when diploid $V$. darrowii rather than tetraploid was used to pollinate diploid $V$. darrowii. The low productivity of the $2 \mathrm{x}-4 \mathrm{x}$ cross is consistent with previous experience with heteroploid crosses in Vaccinium (Darrow et al., 1949; Meader and Darrow, 1944; Rousi, 1966; Sharpe, 1953; Sharpe and Darrow, 1959).

Numerous seedlings were obtained by pollinating diploid $V$. darrowii, FL06-660-I with tetraploid $V$. darrowii. FL06-660-I was used as female parent because, in an early study, it produced numerous fertile hybrids when pollinated by tetraploid $V$. corymbosum (Chavez, 2008). It is unknown whether the seedlings are tetraploid or diploid. A large population of tetraploid $V$. darrowii would permit selection of the best tetraploid plants for crossing with tetraploid highbush blueberry. Tetraploid $V$. darrowii has not been previously reported. Breeding $V$. darrowii at the tetraploid level could produce genotypes with ornamental value. In other experiments, colchicine-derived $V$. darrowii $(4 \mathrm{x})$ was crossed as a female with a colchicinederived $V$. arboreum (4x) plant (FL06-730). Fruit set ranged from $15.8 \%$ to $60.9 \%$ (Table 4 ). In previous studies, crosses between diploid $V$. darrowii and diploid $V$. arboreum gave fruit set ranging from $22.0 \%$ to $79.9 \%$ (Chavez, 2008). Fertile high-vigor amphidiploids are expected from crosses between tetraploid plants of the two species. These plants could be used as ornamentals.

Cytogenetic studies. Chromosome doubling by colchicine was confirmed by cytogenetic studies of $V$. darrowii genotype 40. Chromosome associations at metaphase I included univalents, bivalents, trivalents, and quadrivalents. Chromosome number for genotype 40 averaged $48(2 \mathrm{n}=4 \mathrm{x}=48)$ (Fig. 2). No pollen mother cells (PMCs) were seen in anaphase I or anaphase II. We expected other colchicine-derived plants to have similar chromosome pairing behavior at metaphase I.

\section{Summary}

Screening by stomatal guard cell length and pollen diameter was an effective method of identifying colchicine-derived tetraploid $V$. darrowii plants. Crosses between tetraploid $V$. darrowii identified after colchicine treatment and tetraploid $V$. corymbosum produced numerous seedlings in comparison with analogous crosses using diploid $V$. darrowii. Cytogenetic studies showed that $V$. darrowii genotype 40 

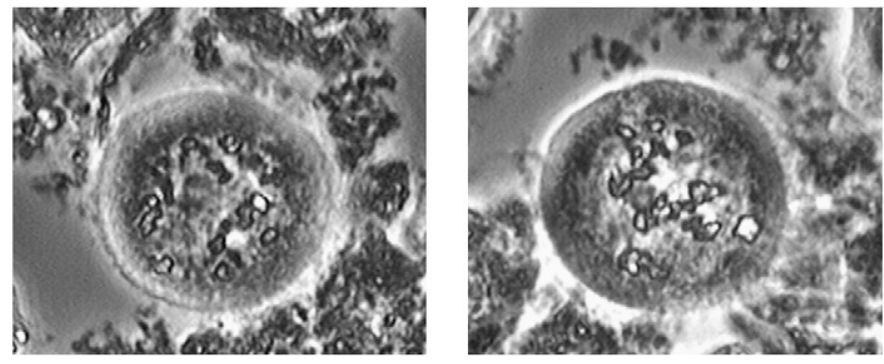

Fig. 2. Cytogenetic studies of meiotic metaphase I in colchicine-derived Vaccinium darrowii FL08-403 $(2 \mathrm{n}=4 \mathrm{x}=48)$ (genotype 40). Left: 8 I, 8 II, 4 III, and 3 IV. Right: 3 I, 5 II, 5 III, and 5IV; 400×.

$(2 \mathrm{x}-4 \mathrm{x})$ was tetraploid in the histogenic layer that produced microspores. Tetraploid $V$. darrowii should be useful in crosses with various tetraploid Vaccinium species.

\section{Literature Cited}

Blakeslee, A.F. 1937. Methods of doubling of chromosomes in plants by treatment with colchicine. J. Hered. 28:393-411.

Brooks, S.J. and P.M. Lyrene. 1995. Characteristics of sparkleberry $\times$ blueberry hybrids. Proc. Florida State Hort. Soc. 108:337-339.

Chandler, C.K. and P.M. Lyrene. 1982. Relationship between guard cell length and ploidy in Vaccinium. HortScience 17:53-54.

Chavez, D.J. 2008. Hybridization of various races of Vaccinium darrowi with cultivated highbush blueberry, $V$. arboreum, and $V$. fuscatum, Univ. Florida, Gainesville, MS Thesis.

Cockerham, L.E. and G.J. Galleta. 1976. A survey of pollen characteristics in certain Vaccinium species. J. Amer. Soc. Hort. Sci. 101:671676.

Darrow, G.M., H. Dermen, and D.H. Scott. 1949. A tetraploid blueberry from a cross of diploid and hexaploid species. J. Hered. 40:304-306.
Den Nijs, T.P.M. and S.J. Peloquin. 1977. 2n gametes in potato species and their function in sexual polyploidization. Euphytica 26:585-600. Dermen, H. 1940. Colchicine polyploidy and technique. Bot. Rev. 6:599-635.

Dermen, H. and H.F. Bain. 1944. A general cytohistological study of colchicine polyploidy in cranberry. Amer. J. Bot. 31:451-463.

Dweikat, I.M. and P.M. Lyrene. 1991. Induced tetraploidy in a Vaccinium elliottii genotype facilitates crossing with cultivated highbush blueberry. J. Amer. Soc. Hort. Sci. 116:1063-1066.

Johnston, S.A., T.P.M. Den Nijs, S.J. Peloquin, and R.E. Hanneman. 1980. The significance of genic balance to endosperm development in interspecific crosses. Theor. Appl. Genet. 57:5-9.

Lyrene, P.M. and J.L. Perry. 1982. Production and selection of blueberry polyploids in vitro. J. Hered. 73:377-378.

Marks, G.E. 1966. The enigma of triploid potatoes. Euphytica 15:285290.

Meader, E.M. and G.M. Darrow. 1944. Pollination of the rabbiteye blueberry and related species. J. Amer. Soc. Hort. Sci. 45:267274.

Moore, J.N. 1965. Improving highbush blueberries by breeding and selection. Euphytica 14:39-48.

Perry, J.L. and P.M. Lyrene. 1984. In vitro induction of tetraploidy in Vaccinium darrowii, $V$. elliottii, and $V$. darrowii $\times V$. elliottii with colchicine treatment. J. Amer. Soc. Hort. Sci. 109:4-6.

Rousi, A. 1966. The use of North-European Vaccinium species in blueberry breeding. Acta Agriculture Scandinavia Suppl. 16:5054.

Sharpe, R.H. 1953. Horticultural development of Florida blueberries. Proc. Florida State Hort. Soc. 66:188-190.

Sharpe, R.H. and G.M. Darrow. 1959. Breeding blueberries for the Florida climate. Proc. Florida State Hort. Soc. 71:308-311.

Sharpe, R.H. and J.S. Shoemaker. 1958. Development of temperateclimate fruits for Florida. Proc. Florida State Hort. Soc. 811:294300.

Woodell, S.R.J. and D.H. Valentine. 1961. Studies in British primulas. IX. Seed incompatibility in diploid-autotetraploid crosses. New Phytol. 60:282-294. 